Archives of Agriculture and Environmental Science

\title{
Investigating the vertical garden applications in Konya City, Turkey: A case study
}

\author{
Safa Aydin Qasim QASIM and Sertaç GÜNGÖR* \\ Selcuk University Faculty of Agriculture Department of Landscape Architecture Konya, TURKEY \\ *Corresponding author's E-mail: sertac@selcuk.edu.tr
}

\section{ARTICLE HISTORY}

Received: 18 January 2019

Revised received: 13 February 2019

Accepted: 18 February 2019

\section{Keywords}

Green façade

Konya/TURKEY

Landscape

Questionnaire

Vertical garden

\begin{abstract}
Vertical garden applications have made serious contributions to the environment not only in terms of aesthetics but also in terms of functionality. In this study, vertical garden samples found in Konya city were examined by being photographed in their places. In order to examine the satisfaction of users, the questionnaire which includes questions under the determined headings (socio-economic structure, field uses, and plant elements, plant species) was applied on a voluntary basis. By calculating the universe size according to the population, a questionnaire composed of 28 questions was applied to 400 people randomly selected from people living in the city of Konya. Frequency distribution analysis of the obtained results was performed using SPSS 20 software. According to the results of the study, vertical gardens are perceived as an aesthetic element in Konya city. People accept that vertical gardens are high-cost applications. When the applications abroad are considered, it can be stated that the applications in Konya city are in the beginning phase.
\end{abstract}

(C)2019 Agriculture and Environmental Science Academy

Citation of this article: Qasim, S.A.Q. and Güngör, S. (2019). Investigating the vertical garden applications in Konya City, Turkey: A case study. Archives of Agriculture and Environmental Science, 4(1): 63-68, https://dx.doi.org/10.26832/24566632.2019.0401010

\section{INTRODUCTION}

Turkey is located as a bridge between Europe and Asia continents. The country's surface area, including lakes is estimated $783,562 \mathrm{~km}^{2}$ of which $755,688 \mathrm{~km}^{2}$ are in Southwest Asia and $23,764 \mathrm{~km}^{2}$ in Europe. It is connected and surrounded by three seas; the Aegean Sea on the west, the Black Sea on the north, the Mediterranean Sea on the south. The Sea of Marmara is also compassed within the north-west side of the country. Turkey has a high topography, and there have been 3 levels of vegetation recorded along with the forest belts as broad-leaved deciduous, coniferous, and alpine grass. The country has a forest cover of 22 million ha which is equal to $27 \%$ of total land cover (Atasoy, 2018a)

Landscape architecture has started to become a branch of the profession of which importance is increasing with each passing day in the world under the effect of urbanization. In cities developing economically, technologically and architecturally, any adverse intervention to green areas in urban centers with the gradual decrease in green areas is met with severe reaction and sanction by the public (Tüfekçioğlu, 2010). In Turkey, production of vertical garden constructions and their profes- sional applications on building surfaces and inside buildings are few. Therefore, this study aims to provide information on the production of vertical gardens in Turkey, as well as to provide a different dimension and new environmental awareness to vertical garden architectural designs and applications for the city of Konya (Çelik et al., 2015).

Nowadays, works in the field of vertical gardens intended for environments both beneficial and respectful to nature and environment, and also suitable for planning, are increasing with each passing day with different application techniques. As a result, increases are observed in the number of vertical gardening applications nowadays (Benazir and Çolakoglu, 2015).Urban green spaces play a significant role in management of physical activity, psychological well-being, and public health of urban residents. With the expansion of urban areas in Turkey during the past decades, urban green spaces have been fragmented and dispersed causing impairment and environmental degradation (Atasoy, 2018b)

\section{Vertical garden}

A cultivated area with vegetation cover spread over the surface of a restricted area is specified as a vertical garden. The first 
vertical garden in Canada was introduced in 1994 at the Canada Life Center Environmental Room in downtown Toronto (Shiah and Kim, 2011). Vegetation can be applied on vertical surfaces and roofs in areas which can carry the plant and living environment statically. However, the pressure on buildings that will originate from the vegetation procedure on walls and roofs should be taken into account. Plant areas made by detecting appropriate surfaces give new identities to the structure and the city. The wall surfaces introduced in modern cities are in the form of high-rise structures along streets, most of which are suitable for vegetation (Tüfekçioğlu, 2010). The concept of a vertical garden is landscape works carried out in the vertical area, and the areas where works will be done may be the facade of a building, piers of a bridge, curtain/boundary wall, sculptures or billboards. In these studies, the surfaces where the vegetation procedure will be performed can be wooden, metal or plastic modular systems, on-site applied and water impermeable felts, wicker fences, walls with no construction on which suction cup plants can hold (Benazir and Çolakoglu, 2015).

\section{Classification of vertical gardens}

\section{Green plant walls}

On green facades depending on the principle of climbing or hanging on the wall, plants can grow by hanging down like traditional systems, or can also be grown upwards. This type of vegetation systems is found in green facade systems (Dunnett and Kingsbury, 2008). Greening systems, green roofs, and green walls are often used as an aesthetic feature in buildings. However, the existing technology in these systems can maximize the functional benefits of facilities. Greening systems are also a component of a sustainable strategy for the improvement of cities and buildings (Manso and Castro-Gomes, 2015).

\section{The modular lattice panel system}

Consists of three-dimensional panels. These systems, which are formed by welding steel wires together, serve as support for vegetation with indentations on both surfaces and aim to prevent damage to the wall structure by keeping the plant away from the wall surface. The panels used in this system can be stacked, assembled, and are suitable for covering large areas and can be applied not only on flat surfaces but also on curved surfaces (Aygencel, 2011).

The purpose of the drip irrigation system is to give the water needed by the plant to a certain part of the plant's bottom frequently and in small amounts, through pipes with a smaller cross-sectional area. Besides the mentioned advantages, the main disadvantage of the drip irrigation method is that the first facility costs are high. There are also problems such as a dripper blockage. For the solution of this problem, taking preventive measures, such as filtration of irrigation water, application of chemicals such as acid and/or chlorine, flushing of pipes with pressurized water by opening them from their blind plugs, and visual monitoring of the system, eliminates these negativities (Anonymous, 2012).
In the cable and wire mesh network system

Which is solved in the form of two systems, while cables are used with fast-growing climbing plants in intensive vegetation, wire nets are used with slower growing plants? Plants growing on wire nets need additional support. Such networks are more flexible and provide a more extensive degree of grading in applications than cables. Both systems use high-quality reinforcements. Flexible vertical and horizontal wire ropes of various sizes and models are formed by being connected to each other with the help of cross clamps (Yücel and Elgin, 2010). In cable wire mesh network systems, the support systems, which are needed to hold clinging and climbing plants, are usually positioned away from the facades. The distance between the facade and the system depends on the growth of plants. Plants that hold on the system with their spines or shoots spread on the system like a curtain.

\section{Vertical garden benefits}

\section{Improving indoor air quality}

The environmental protection organization has considered indoor air quality as one of the first five health concerns. The importance of indoor air quality has been understood by determining that people are at a higher risk of catching an illness in schools, offices, and closed areas. Vertical garden systems, which increase the number of green areas in cities, retain exhaust gases and dust in the air thanks to the leaves and roots of plants within their structure. Plants also produce oxygen by taking $\mathrm{CO}_{2}$ from the air. Harmful gases and dust retention amounts vary according to the form, leaf structure and texture of the plants used in vertical garden systems (Mir, 2011).

\section{Reducing the heat island effect}

While green areas and evaporation surfaces in cities are decreasing, the increase in concrete and asphalt surfaces leads to local and regional climate changes. This is effective in the formation of the climates specific for each city. This climatic variation in urban areas is called the "urban heat island." In 1820, Luke Howard examined heat differences between urban and rural areas of London and introduced the concept of "urban heat island" for the first time in the literature (Yüksel, 2013). The temperature relationship between direct green facades, indirect green facades, and living walls was studied by Dutch researchers. They found out that they blocked the air behind the walls 4 $\mathrm{cm}$ from the building. These properties are preferred in order to protect buildings against cold climates (Safikhani et al., 2014).

\section{Reducing noise pollution}

Urbanization, the presence of industry, the sounds of motor vehicles in traffic create sound pollution above the sound level that the human can perceive. This noise pollution is one of the most important elements that disturb people. Since the factors that make up noise pollution cannot be eliminated, the authorities propose various solutions to bring the noise to the level that people can least feel (Öztürk, 2010). In order to prevent noise, a single plant usage is not sufficient, and it is essential that plants 
reach as deep as possible and the height of at least $5 \mathrm{~m}$ for effective use. Furthermore, plants should be of a certain height and at a certain frequency and should be reinforced with walls (Özden and Cengiz, 2015).

\section{Biodiversity}

Due to the concrete areas in the city center, fauna which has difficulty in finding the living area becomes part of an ecosystem thanks to vertical gardens, and this set of plants provides living space for insects and other animals. Vertical gardens also form a feeding and resting area for birds (Öztan, 1991).

\section{Collection of dust particles}

One of the best solutions to eliminate the effect of dust caused by the movement of the debris lifted by the wind from dry surfaces in the air space is vegetation. While plants hold dust particles, they also destroy harmful microorganisms with their sap or secretions (Öztan, 1991).

\section{Creating agricultural land}

According to Gül (2008), the problems experienced in agricultural lands, production-consumption amounts not meeting each other, efforts to create production areas in cities have brought landless production techniques to the forefront, and the idea of agriculture through vertical garden systems has been introduced. In the vertical garden system, the use of pesticides and herbicides that pollute nature is minimized. An increase in food price is prevented. Inefficiency experienced in agricultural lands is eliminated. It contributes to the national economy by saving water consumption (Bingöl, 2015).

\section{MATERIALS AND METHODS}

The main material of our research is the literature on vertical gardening, the applications made by the municipality, published books, articles and journals. The information obtained as a result of the interviews with the vertical gardener companies and the photographs taken in the field are the material of the study. In the city of Konya, streets, houses, pavilions, university campuses, parks, intersections and green walls and vertical garden samples on underpasses and vertical garden samples made in the world are examined together.

The method of the study consists of 4 stages with outline. These stages are as follows.

1-Stage: Determination of the study area (Vertical garden application in the city of Konya).

a. In the Seljuk district, the Sille underpass junction, the underpass junction, the Rauf Denktas subway, the Butterflies Valley, The Cultural Park, the Selcuker Center, Selcuk University. Dr. Erol Güngör Library and Campus front.

b. Villas located in Meram District.

c. Parks and intersections.
2-Stage: Literature research and data collection: Information about the study area, the information obtained from the interviews with the firms on the days of vertical gardening, the interviews with the municipal authorities and the information on the irrigation systems of the plants used were collected.

3-Stage: Survey application with the help of the Google Survey program, on Facebook and Instagram shared by the groups related to Konya and the local residents and local residents face to face on the basis of volunteerism and random, the data obtained from surveys and Google questionnaires in the area were also investigated by SPSS 20. software.

According to Efe et al. (2000), with the chi square conformity test, the observed frequencies of the different categories of a given variable were investigated for their suitability to the expected frequencies.

\section{RESULTS AND DISCUSSION}

The questionnaire consists of two parts: In the first part; questions to determine the demographic characteristics of the users (gender, age, occupation, marital status, monthly income and educational status); in the second part, there are general questions about vertical garden applications in Konya.

Five-point Likert-type answers were accepted in the questionnaires, and if the questions in the survey were about an event or people, the scales to be used were called Likert, Turstone or Gutman scale (Arseven, 2004).

According to State Statistical Institute data, the population of Konya is 2.195 .410 people. $49.5 \%$ of the population is male, \% 50,5 female. In Konya, Selcuklu, Meram and Karatay districts are the most densely populated districts. Sample size was found with formula (384). A questionnaire was applied to 400 people in case of error or invalidation.

12 places were visited in this thesis. Structural and vegetative findings related to the applications of vertical gardens have been reached. In our study, samples taken in vertical garden application areas in Konya city have been examined. Some private villas do not have access to their gardens.

Reduction in green areas has caused various environmental problems. People squeezed between concrete structures are looking for various ways to overcome their psychological problems and to meet their longing for green. One of these is vertical gardens and green walls. The purpose of vertical gardens and green walls, which arise from the studies of different disciplines (landscape architects, architects, engineers, etc.), is to close the cold image of concrete and increase the visual value. In these systems, nature and structures are integrated, and thus, urban areas and the desired environment have become intertwined.

There are many examples of vertical garden designs in the world created with different materials and methods. There are companies engaged in these activities in Turkey, but they are inexperienced. In vertical garden applications, selection of the right plant and the right material is significant in terms of climate. 
Designs may become inadequate in terms of sustainability when these applications are planned incorrectly or due to deficiencies in the maintenance process. In addition to sustainability, it can cause the loss of functionality.

In vertical garden studies, there is a difference between our country and abroad. In addition to aesthetics abroad, functionality is in the foreground. It is observed that vertical gardens and green walls in Konya are generally made for aesthetics rather than functionality. Vertical gardens in Konya were used as aesthetic elements in the city's underpasses and city squares, without seeking functionality. However, green facades (Meram villa houses) were used functionally for the purpose of screening in private mansions.

Plant species used in vertical garden applications in Konya are limited in comparison with abroad. This is because of the systems used, location selection, and climate conditions. Villa houses in the district of Meram in Konya went down in history with their green facades. The low-cost and fast-growing clinging and climbing plants which are used for screening purposes have been aesthetically attractive also with their leaves.

According to Misgav (2000), the visual quality and evaluation of landscape architecture is determined based on the satisfaction of the users according to their responses. According to the survey responses, it was determined that the participants were composed of gender numbers (50\% male and 50\% female). According to age variables of the participants, it is between the ages of $50.8 \%(18-25)$ and the least participant is 6.8\% (36-45). When the distribution of occupation status is examined, it is observed that $46.3 \%$ of students and at least 3.8 workers participated in the study. When we examine their marital status, $75.8 \%$ of the respondents are single and $24.2 \%$ are married. When the educational status of the surveys is examined, the highest rate is $51 \%$ for university graduates. The answers given by the 400 respondents are given in Table 1.

Table 1. Number of answers given by the participants of the survey (Total Questionnaire: 400).

\begin{tabular}{|c|c|c|c|c|c|}
\hline Questions & $\begin{array}{l}\text { Strongly } \\
\text { Agree }\end{array}$ & Agree & Neutral & Disagree & $\begin{array}{l}\text { Strongly } \\
\text { Disagree }\end{array}$ \\
\hline $\begin{array}{l}\text { 1- I believe that it is required to improve the quality of life of people living } \\
\text { in urban areas. }\end{array}$ & 191 & 138 & 43 & 9 & 19 \\
\hline 2- Vertical gardens reduce noise pollution. & 128 & 164 & 77 & 25 & 6 \\
\hline 3-Vertical gardens increase air quality in indoor and outdoor areas. & 172 & 147 & 51 & 28 & 2 \\
\hline 4- The use of vertical gardens reduces energy and water consumption. & 58 & 147 & 125 & 68 & 2 \\
\hline 5- The use of vertical gardens reduces the urban heat island effect. & 114 & 144 & 106 & 30 & 6 \\
\hline 6- I think that vertical gardens have a relaxing and calming effect. & 161 & 177 & 44 & 7 & 11 \\
\hline $\begin{array}{l}7-\text { I think that the cost of the vertical garden is high (As of } 2018 \text {, the cost } \\
\text { of one square meter of the vertical garden is between } 600-1200 T L \text { ). }\end{array}$ & 86 & 107 & 152 & 42 & 13 \\
\hline 8- Plant design in vertical gardens looks beautiful. & 195 & 139 & 44 & 6 & 16 \\
\hline 9- I think the vertical garden is an original design. & 132 & 171 & 61 & 28 & 8 \\
\hline 10- I think the vertical garden adds naturalness to the environment. & 135 & 173 & 55 & 25 & 12 \\
\hline 11- Vertical gardens bring a memorable character to places. & 146 & 174 & 53 & 20 & 7 \\
\hline 12- There is a variety in vertical garden designs. & 120 & 191 & 59 & 23 & 7 \\
\hline $\begin{array}{l}\text { 13- I think that plant design in vertical gardens adds complexity to the } \\
\text { environment. }\end{array}$ & 32 & 85 & 83 & 152 & 48 \\
\hline $\begin{array}{l}\text { 14- Vertical gardens are among the determining factors for visiting a } \\
\text { place. }\end{array}$ & 59 & 133 & 141 & 54 & 13 \\
\hline 15-I think it is inconvenient to use the vertical garden indoors. & 9 & 84 & 123 & 126 & 48 \\
\hline 16- I'd like to see vertical gardens of different styles in the places I go. & 143 & 169 & 60 & 21 & 7 \\
\hline 17- I think that vertical gardens can be applied in every place. & 71 & 132 & 97 & 77 & 23 \\
\hline 18-I think that vertical gardens are aesthetic. & 118 & 185 & 68 & 29 & 0 \\
\hline 19- The application quality of vertical gardens in Konya is unproblematic. & 25 & 103 & 157 & 73 & 42 \\
\hline 20- Vertical gardens have a functional feature. & 81 & 207 & 100 & 10 & 2 \\
\hline $\begin{array}{l}21 \text { - Vertical gardens affect urban transportation during the construction } \\
\text { process. }\end{array}$ & 38 & 129 & 131 & 75 & 27 \\
\hline 22- Vertical gardens have an aesthetic feature. & 113 & 215 & 42 & 23 & 7 \\
\hline 23- Vehicles are endangered when the irrigation network is not done well. & 80 & 168 & 88 & 45 & 19 \\
\hline $\begin{array}{l}\text { 24- Municipalities need to spend money on social issues instead of } \\
\text { establishing vertical gardens. }\end{array}$ & 57 & 72 & 100 & 130 & 41 \\
\hline 25-Vertical garden patterns distract the attention of drivers. & 34 & 101 & 106 & 131 & 28 \\
\hline $\begin{array}{l}\text { 26- Vertical gardens in Turkey are used for aesthetic purposes rather } \\
\text { than functionality. }\end{array}$ & 81 & 204 & 91 & 13 & 11 \\
\hline $\begin{array}{l}\text { 27- What do you think is the most suitable plant species for vertical } \\
\text { gardens? (Herbaceous plant, Seasonal flower, Perennial) }\end{array}$ & $\begin{array}{c}97 \\
\text { Herbaceous } \\
\text { plant }\end{array}$ & $\begin{array}{c}225 \\
\text { Seasonal } \\
\text { flower }\end{array}$ & $\begin{array}{c}78 \\
\text { Perennial } \\
\text { flower }\end{array}$ & - & - \\
\hline $\begin{array}{l}\text { 28- What is your expectation from the vertical garden (Functionality, } \\
\text { aesthetics, color effect, climate smoothing effect)? }\end{array}$ & $\begin{array}{c}96 \\
\text { Functionality }\end{array}$ & $\begin{array}{c}94 \\
\text { Aesthetics }\end{array}$ & $\begin{array}{c}90 \\
\text { Color } \\
\text { effect }\end{array}$ & $\begin{array}{c}120 \\
\text { climate } \\
\text { smoothing } \\
\text { effect }\end{array}$ & - \\
\hline
\end{tabular}


Conclusion

According to the survey about the vertical garden and green walls in Konya, the result is as follows.

- It is seen that it increases the quality of urban life, air quality and reduces the noise pollution.

- Vertical garden energy and water use also reduces the effect of urban heat.

- Vertical gardens have a relaxing effect.

- Most of the people think that Vertical gardens are expensive.

- It is thought that the vertical garden is an original design, it looks beautiful in terms of vegetative design, and it is thought to add naturalness to the environment.

- Vertical garden design due to the diversity of solidarity gives the place a memorable quality.

- Vertical gardens do not consider complexity of vegetative design to the environment, but they find these spaces to be aesthetic.

- The vertical gardens see them as specific factors for going to a space, they can be applied in every space and they want to see vertical gardens in different styles.

- There was no problem in the application quality of vertical gardens in Konya.

- Vertical garden during the plant phase of the road part of the city due to the transportation is affected. In addition, after the construction of the irrigation network is not done well put the vehicles in danger.

- Vertical gardens are important for public health and social issues are required to be given as much importance.

- Vertical gardens do not distract the driver.

- Plant species used in vertical gardens (respectively according to the preference of the survey participants) are seasonal flowers, herbaceous plants and perennines.

- Expectations from vertical gardens (respectively according to the preference of the survey participants); the effect of climate smoothing, functionality, aesthetics and color have been the effect.

\section{ACKNOWLEDGMENT}

This article is part of the M.Sc. thesis supervised by Associate Prof. Dr. Sertaç GÜNGÖR (accepted by Selcuk University Natural and Applied Sciences). We thank the referees for their valuable comments on our paper, which have considerably improved the presentation of this paper.

\section{Conflict of interest}

The authors declare there are no conflicts of interest.

Open Access: This is an open access article distributed under the terms of the Creative Commons Attribution 4.0 License, which permits unrestricted use, distribution, and reproduction in any medium, provided the original author(s) if the sources are credited.

\section{REFERENCES}

Anonymous. (2012). Drip irrigation (Turkish: Damla Sulama) Accessed on 13/5/2018 from http//www. agplastik.com/ ? $\operatorname{mid}=206 \& \mathrm{~L}=\mathrm{TR}$

Arseven, A. (2004). Survey Preparation, Field Research (Turkish: Anket Hazırlama, Alan Araşturmaları için), Gündüz Education and Press, Ankara, s10.

Atasoy, M. (2018a). A check list of Mediterranean plants to control erosion in Turkey. ISJ Theoretical \& Applied Science, 11 (67): 147-152.

Atasoy, M. (2018b). Monitoring the urban green spaces and landscape fragmentation using remote sensing: a case study in Osmaniye, Turkey. Environmental Monitoring and Assessment, 190(12): 713.

Aygencel, M. (2011). Vertical Green Systems. (Turkish: Dikey Yeşil Sistemler). MSc Thesis, Karadeniz Tecknical University, Graduate School of Natural and Applied Sciences, Trabzon, Türkiye.

Benazir, Ö. and Çolakoglu, E. (2015). The Status of Development Agencies within the Turkish Administrative Organization with Regard to Regional Development). Atatürk University (Turkey) Journal of Economics and Administrative Sciences, 29 (2).

Bingöl, B. (2015). Vertical farming. Düzce University Journal of Forestry (Orman Fakültesi Ormancılık Dergisi), 11 (2): 92-99.

Çelik, A. Ender, E. and Zencirkiran, M. (2015). Vertical Gardens and Applications in Turkey (Turkish: Dikey Bahçe ve Türkiye'deki Uygulamaları), Research Journal of Agricultural Sciences (Tarım Bilimleri Araştırma Dergisi) (1): 67-70.

Dunnett, N. and Kingsbury, N. (2008). Planting green roofs and living walls. Timber press Portland.

Efe, E. Bek, Y. and M. Şahin, M. (2000). Statistical Methods with Solutions in SPSS II. (Turkish: SPSS'te Çözümleri ile İstatistik Yöntemler II). Kahramanmaraş Sütçüİmam University Press No: 73, School Book No: 9, K.S.Ü. Press, Kahramanmaraş/Turkey. $214 \mathrm{~s}$

Gül, A. (2008). Hydroponic Method (Turkish: Topraksız Tarım), Hasad Press, 144s.

Manso, M. and Castro-Gomes, J. (2015). Green wall systems: a review of their characteristics, Renewable and Sustainable Energy Reviews, 41, 863-871.

Mir, M.A. (2011). Green façade and Building Structures Delft University of Technology, Delft.

Misgav, A. (2000). Visual preference of the public for vegetation groups in Israel, Landscape and Urban Planning, 48 (3-4): 143-159.

Özden, M. and Cengiz, E. (2015). Tourism, Environment and Sustainability. Chapter 35. The Value of Urban Green Infrastructure for Sustainability of Urban Ecosystems. Editors: Avcıkurt, C., Dınu, M., Hacıoğlu, N., Efe, R. ve Soykan, A., ISBN 978-954-07-4021-8. St. Kliment Ohridski University Press Sofia. 
Öztan, Y. (1991). What should be the open and green space system of Ankara city for 2000s?, Possibilities of Open and Green Area System for 2000s of Ankara City (Turkish: 2000'li Yıllar için Ankara Kenti'nin Açık ve Yeşil Alan Sistemi Ne Olmalıdır?', Landscape Architecture Magazine (Peyzaj Mimarlığı Dergisi), 2, 91.

Öztürk, H. (2010). Formation of the Noise Map by Measuring Noise Levels in Kirklareli City Center (Turkish: Kırklareli il merkezi gürültü düzeylerinin belirlenerek gürültü haritasının oluşturulması). Republic of Turkey Trakya University Institute of Health Sciences. MSc Thesis. Edirne.

Safikhani, T. Abdullah, A.M. Ossen, D.R. and Baharvand, M. (2014). Thermal impacts of vertical greenery systems, Environmental and Climate Technologies, 14 (1), 5-11.

Shiah, K. and Kim, W.J. (2011). An investigation into the applica- tion of vertical garden at the new sub atrium. University of British Columbia, Social Ecological Economic Development Studies (Seeds) Student Report, APSC 261, Canada.

Tüfekçioğlu, İ. (2010). Challenge to Gravity: Gardens (Yurkish: Yerçekimine Meydan Okuyan Bahçeler), GEO Magazine, s: 39-40.

Yücel, G. and Elgin, Ü. (2010). Wall Garden/Vertical Garden/ Green Wall (Turkish: Duvar Bahçesi: Dikey Bahçe/Yeşil Duvar), Mavi Yapı Magazine, Year, 1 (2), 51-53.

Yüksel, N. (2013). Vertical Garden Applications İnvestigation Example of Abroad And İstanbul (Turkish: Dikey Bahçe Uygulamalarının Yurtdışı ve İstanbul Örnekleri ile İrdelenmesi, Bahçeşehir University Graduate School of Natural and Applied Sciences Urban Systems and Transport Management. MSc Thesis. İstanbul, page 85. 